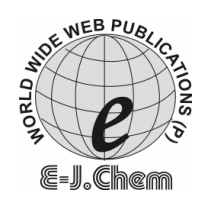

ISSN: 0973-4945; CODEN ECJHAO

E-Journal of Chemistry

http://www.e-journals.net

2009, 6(4), 1117-1120

\title{
UV Spectrophotometric Estimation of Acipimox in Bulk and Capsule Dosage Form
}

\author{
A. ELPHINE PRABAHAR, B. THANGABALAN*, \\ R. KALAICHELVI ${ }^{\S}$ and P. VIJAYARAJ KUMAR ${ }^{\#}$ \\ Department of Pharmacy, Donbosco PG College, \\ Vatticherukuru Mandal, Guntur-522 017, India. \\ ${ }^{\S}$ K.C.Reddy Institute of Pharmaceuatical Sciences, Jangamguntla Palem, \\ Medikonduru Mandal, Guntur-522 348, India. \\ \#Bharat Institute of Pharmacy, Mangalpally Village, \\ Ibrahimpatnam. RR Dist.-501506, India. \\ bthangabalan@gmail.com
}

Received 18 February 2009; Accepted 15 April 2009

\begin{abstract}
A new simple, rapid, accurate, sensitive and precise spectrophotometric method in ultra violet region has been developed for determination of acipimox (ACX) in bulk and capsule dosage form. Acipimox exhibited maximum absorbance at $231 \mathrm{~nm}$ with apparent molar absorptivity of $1.5104 \times 10^{4}$ in distilled water. Beer's law was found to be obeyed in the concentration range 1-10 $\mu \mathrm{g} \mathrm{mL} \mathrm{m}^{-1}$. Correlation coefficient was found to be 0.9998. The developed method was validated respect to linearity, precision, accuracy. The proposed method is useful for the routine estimation of ACX in bulk and capsule dosage form.
\end{abstract}

Keywords: UV Spectrophotometry, Acipimox, Beer's law, Capsule analysis.

\section{Introduction}

Acipimox, chemically 5-methylpyrazine carboxylic acid 4-oxide (Figure 1), is a nicotinic acid analogue which is an antilipolytic drug used in the management of different forms of hyperlipidaemia ${ }^{1-3}$. Literature survey reveals that the drug can be estimated only by HPLC ${ }^{4}$ and no spectrophotometric methods have been reported. The present study describes a simple, sensitive, accurate and precise spectrophotometric method for estimation of ACX in bulk and capsule formulation. UV analysis of ACX was performed in distilled water. The spectrum was recorded from $200 \mathrm{~nm}$ to $400 \mathrm{~nm}$. The quantitative analysis was carried out at $231 \mathrm{~nm}$. The method was validated and applied for the determination of ACX in capsule dosage form. 
<smiles>Cc1cnc(C(=O)O)c[n+]1[O-]</smiles>

\section{Experimental}

Figure 1. Chemical structure of acipimox.

The spectrophotometric measurements were carried out using Elico UV/Visible double beam spectrophotometer SL-164 with $1 \mathrm{~cm}$ matched quartz cells.

\section{Reagents}

ACX was tested for purity by measuring its melting point and IR spectra and no impurities were found. Doubly distilled water of analytical grade was used. A pharmaceutical preparation of ACX was obtained from local pharmacy.

\section{Standard solutions}

Standard stock solution of ACX $\left(1000 \mu \mathrm{g} \mathrm{mL}^{-1}\right)$ was prepared in distilled water. It was further diluted to obtain $1,2,3,4,5,6,7,8,9$ and $10 \mu \mathrm{gL}^{-1}$ with distilled water. The absorbance was measured at $231 \mathrm{~nm}$ against distilled water as blank. The calibration curve was plotted in the concentration range of 1 to $10 \mu \mathrm{g} \mathrm{mL}^{-1}$ of ACX in distilled water.

\section{Sample solutions}

Twenty capsules containing ACX were weighed accurately and emptied. The powder equivalent to $100 \mathrm{mg} \mathrm{ACX}$ was dissolved in $20 \mathrm{~mL}$ of distilled water, sonicated for 15 minutes and filtered through Whatman No. 41 filter paper. The residues were washed thoroughly with distilled water and further diluted with distilled water to $5 \mu \mathrm{g} \mathrm{mL}{ }^{-1}$ concentrations and the absorbance measured at $231 \mathrm{~nm}$ against distilled water as a blank.

\section{Results and Discussion}

The UV spectrum of standard solutions of ACX in distilled water was illustrated in Figure 2. The optical characteristics such as Beer's law limit', molar absoptivity, Sandell's sensitivity ${ }^{6}$, slope and intercept are summarized in Table 1 . The assay and precision studies results for capsules containing ACX are shown in Table 2.



Figure 2. UV spectrum of Acipimox in distilled water. 
Table 1. Optical characteristics of proposed method.

\begin{tabular}{lll}
\hline Parameters & Values \\
\hline$\lambda_{\text {max }}, \mathrm{nm}$ & 231 \\
Beer's law limit, $\mu \mathrm{g} \mathrm{mL} \mathrm{m} \mathrm{cm}^{-1} / 0.001$ absorbance unit & $1-10$ \\
Sandell's sensitivity, $\mu \mathrm{g} \mathrm{cm}^{-1} / 75 \times 10^{-5}$ \\
Molar absorptivity, $\mathrm{L} \mathrm{mol}^{-1} \mathrm{~cm}^{-1}$ & & $1.5104 \times 10^{4}$ \\
Regression equation, $\mathrm{Y}=\mathrm{a}+\mathrm{bc}$ & \\
& Slope (b) & 0.0978 \\
& Intercept(a) & 0.0002 \\
Correlation coefficient, $\mathrm{r}^{2}$ & & 0.9998 \\
\hline
\end{tabular}

\section{Validation}

The assay of ACX was validated with respect to stability, linearity, precision and accuracy.

\section{Stability}

The standard stock solutions of ACX were stored, in two different conditions, at $+4{ }^{0} \mathrm{C}$ and at ambient temperature for one month. During this period, the solutions were analyzed with UV spectrophotometric method, the spectrum was compared with the spectrum of daily prepared standard solution and no difference was obtained between them. It is decided that ACX is highly stable in the mentioned conditions.

\section{Linearity and range}

In developed UV method, calibration curve was linear in the range from 1 to $10 \mu \mathrm{gL}^{-1}$ of ACX.

\section{Precision}

\section{Inter-day precision}

This was done by analyzing formulation by same analyst for six days subsequently. The $\%$ RSD values are shown in Table 2.

\section{Intra-day precision}

This was done by analyzing formulation in same day for six times of individual preparation and observation. The \% RSD and data are shown in Table 2.

Table 2. Assay results and precision studies.

\begin{tabular}{|c|c|c|c|c|c|c|}
\hline \multirow[b]{2}{*}{ Sample } & \multirow{2}{*}{$\begin{array}{l}\text { Labeled amount, } \\
\text { mg/ capsule }\end{array}$} & \multirow{2}{*}{$\begin{array}{l}\text { Amount } \\
\text { found in } \mathrm{mg} \text { * }\end{array}$} & \multirow{2}{*}{$\begin{array}{c}\%, \text { label } \\
\text { claim* } \pm \text { S.D }\end{array}$} & \multicolumn{3}{|c|}{ Precision** } \\
\hline & & & & Repeatability & Inter-day & Intra-day \\
\hline $\begin{array}{l}\text { Acipimox } \\
\text { capsules }\end{array}$ & 250 & 249.96 & $99.92 \pm 0.293$ & 0.268 & 0.0068 & 0.0043 \\
\hline
\end{tabular}

* Average of six determinations. **SD of five determinations

\section{Accuracy}

Recovery studies were performed to judge the accuracy of the method. Recovery studies were carried out by adding a known quantity of pure drug to a pre-analyzed formulations and the proposed method was followed. From the amount of drug found, percentage recovery was calculated. The results of analysis and recovery studies are given in Table 3. 
Table 3. Recovery study.

\begin{tabular}{ccccccc}
\hline Drug & $\begin{array}{c}\text { Label claim Estimated } \\
\text { mg /capsule }\end{array}$ & $\begin{array}{c}\text { Spike } \\
\text { level, \%ount } \%\end{array}$ & $\begin{array}{c}\text { Amount } \\
\text { of drug } \\
\text { added, mg }\end{array}$ & $\begin{array}{c}\text { Amount } \\
\text { of drug } \\
\text { recovered, mg }\end{array}$ & $\begin{array}{c}\text { Percentage } \\
\text { Recovery } \pm \\
\text { SD* }\end{array}$ \\
\hline $\begin{array}{c}\text { Acipimox } \\
\text { capsules }\end{array}$ & 250 & 249.96 & 100 & 5.0 & 4.03 & $100.72 \pm 0.6473$ \\
& & & 120 & 6.0 & 6.98 & $99.50 \pm 0.4235$ \\
\hline
\end{tabular}

\section{Conclusion}

*Mean of six determinations

In this study a simple and rapid UV spectrophotometric method for the determination of ACX in bulk and pharmaceutical formulation has been developed and validated.

\section{References}

1. Ericsson S, Eriksson M and Angelin B, Eur J Clin Invest., 2008, 20, 261-265.

2. Saloranta C, Taskinen M R, Widen E, Härkönen M, Melander A and Groop L, Diabetes, 1993, 42, 1559-1566.

3. Alessio D, Gabriella C, Cristiano C and Zina G, Exp Gerontol., 2004, 39, 1061-1067.

4. Musatti L, Maggi E, Moro E, Valzelli G and Tamassia V, J Int Med Res., 1981, 9, 381-386.

5. Beckett H A and Stenlake B J, Practical Pharmaceutical Chemistry; $4^{\text {th }}$ Ed., CBS Publishers, New Delhi, 2001, 275.

6. Sandell E B, Colorimetric determination of traces of metals; Inter Science, New York, 1950, 29. 


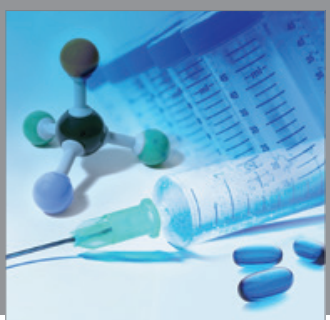

International Journal of

Medicinal Chemistry

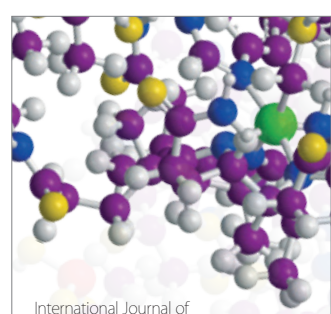

Carbohydrate Chemistry

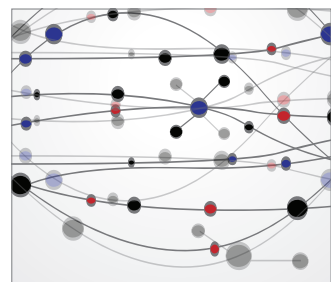

The Scientific World Journal
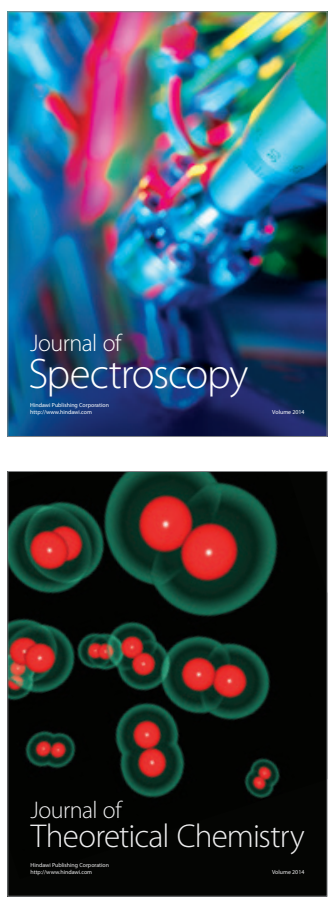
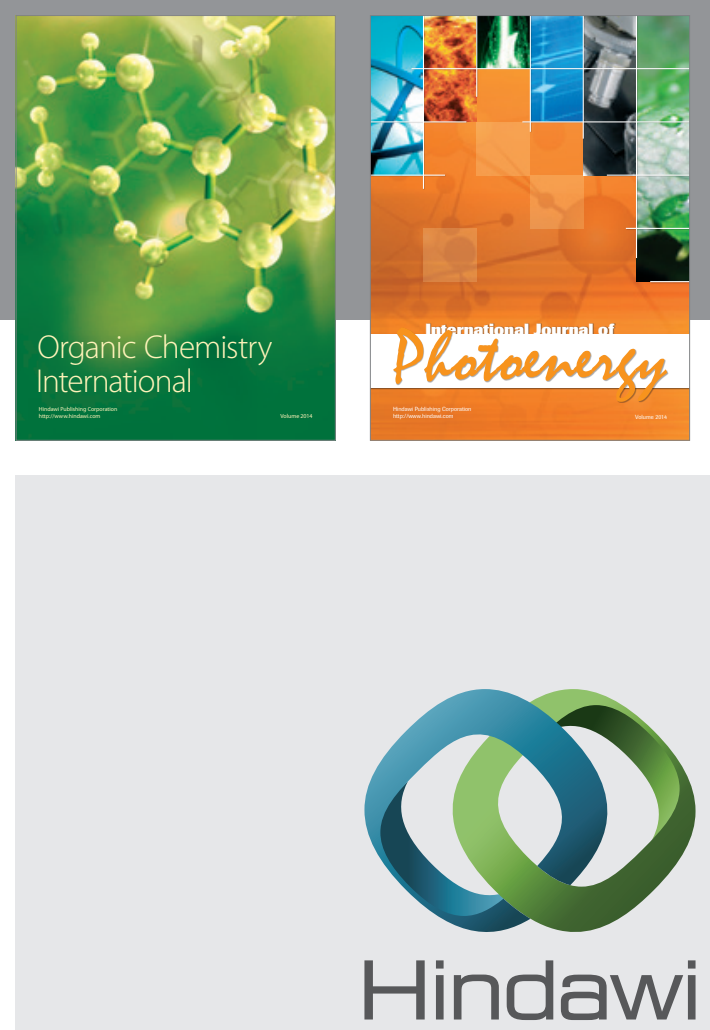

Submit your manuscripts at

http://www.hindawi.com

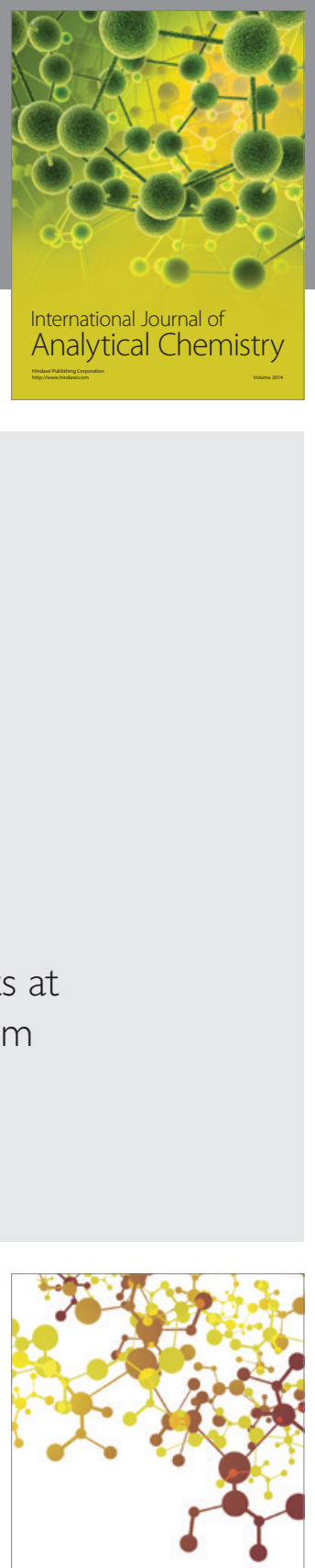

Journal of

Applied Chemistry
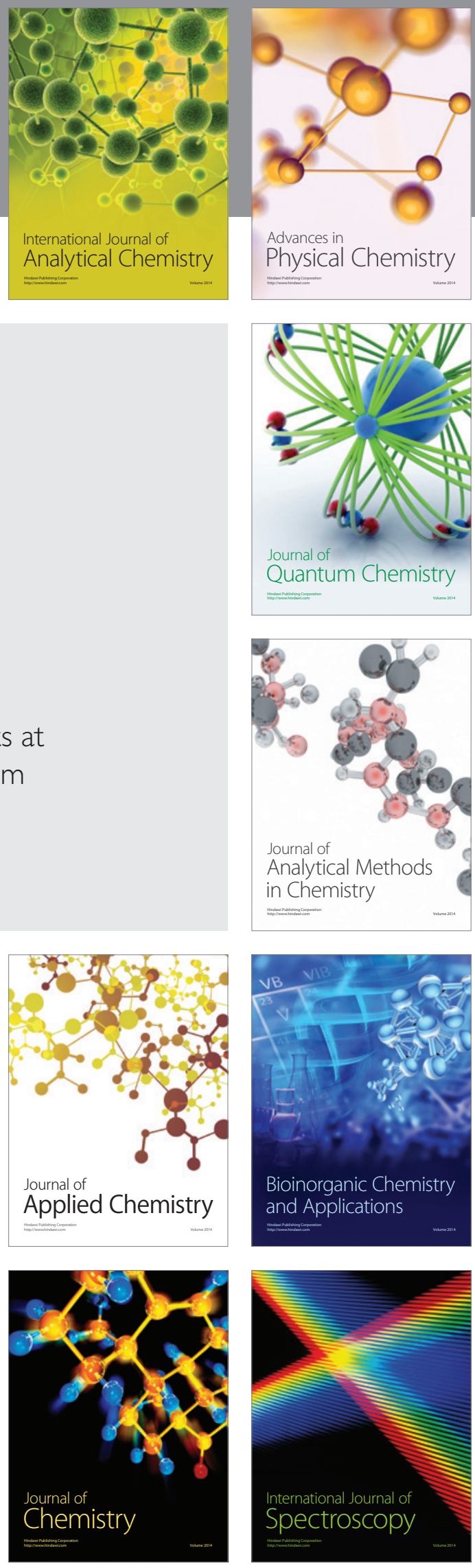